\title{
SELECTED LIST OF WMO PUBLICATIONS
}

Distributed by

The American Meteorological Society

45 Beacon Street

Boston, MA 02108

All prices listed below are quoted in U.S. Dollars. (Availability and prices are subject to change without notice.) Orders and inquiries from residents of U.S.A. and Canada should be directed to: American Meteorological Society, Attn: WMO Publication Center, 45 Beacon Street, Boston, MA 02108, U.S.A. Residents of all other countries should direct orders and inquiries to: World Meteorological Organization, Publications Sales Unit, P.O. Box No. 5, CH-1211 Geneva 20, Switzerland.

Remittance must accompany all orders; only after receipt of payment will the order be processed. Add $\$ 4.00$ per book for postage and handling. Payment from Canadian clients must be made by a draft on a U.S. Bank or by International Money Order. Checks or money orders should be made payable to the AMS in U.S. dollars.

\section{New Technical Notes:}

679 - The Contribution of Satellite Data and Services to WMO Programmes in the Next Decade, T.N. $189 ; 1988$

$\$ 34.00$

684 - Weather, Climate and Animal Performance, T.N. 190; 1989

$\$ 26.00$

687 - Agrometeorological Aspects of Operational Crop Protection, T.N. 192; 1989

$\$ 25.00$

703 - Agroclimatology of the Sugar-Cane Crop, T.N. 193; 1989

$\$ 18.00$

\section{New Operational Hydrology Reports:}

680 - Manual on Water-Quality Monitoring, O.H.R. 27; 1988

$\$ 22.00$

683 - Hydrological Information Referral Service - INFOHYDRO Manual, O.H.R. 28; 1987

$\$ 46.00$

704 - Hydrological Aspects of Combined Effects of Storm Surges and Heavy Rainfall on River Flow, O.H.R. 30;

$\$ 15.00$ 1989

705 - Management of Groundwater Observation Programmes, O.H.R. 31; 1989

$\$ 18.00$

WMO Bulletin - Quarterly Subscription ${ }^{\circ}$

Number of Years

2

3
Surface Mail

$\$ 48.00$

78.00

109.00
Airmail

$\$ 66.00$

107.00

150.00

WMO 5 - Composition of the WMO - Quarterly Subscription ${ }^{\circ}$

${ }^{\circ}$ Subscriptions to WMO Bulletin and WMO 5 are accepted on calendar year basis

Number of Years

$\begin{array}{cr}1 & \$ 60.00 \\ 2 & 110.00 \\ 3 & 150.00 \\ \text { Single issue } & 17.00\end{array}$

Airmail

$\$ 77.00$

145.00

200.00

20.00

WMO No.

\$ Unit Price

\section{Atlases}

Climatic Atlas of Europe. Volume I: Maps of Mean Temperature and Precipitation

Climatic Atlas of South America. Volume I: Maps of Mean Temperature and Precipitation

Climatic Atlas of North and Central America. Volume I: Maps of Mean Temperature and Precipitation

197.00

172.00

Climatic Atlas of Asia. Volume I: Maps of Mean Temperature and Precipitation

202.00

47.00

International Cloud Atlas, Abridged Edition, 1956

International Cloud Atlas - Manual on the Observation of Clouds and other Meteors, 1987

Volume I - Text (out of print)

Volume II - Color Plates

78.00

659 - Marine Cloud Album, 1987

20.00

\section{Basic Documents}

15 - Basic Documents No. 1 - (Excluding Technical Regulations), 3rd Edition, 1987

34.00

60 - Basic Documents No. 3 - Agreements and Working Arrangements With Other International Organizations, 1988*

\section{Technical Regulations}

49 - Technical Regulations - Basic Documents No. 2 (loose leaf; please specify if cover is needed)

Vol. General, 2nd Edition, 1984

Vol. II Meteorological Service for International Air Navigation, 1988 Editiont

Vol. III Hydrology, 1988 Editiont

One cover will accommodate both volumes.

555 - Technical Regulations - Hydrology and International Hydrological Codes, 1980

17.00 (cover)

24.00

558 - Manual on Marine Meteorological Services, 1981

\footnotetext{
* In preparation

+ Currently out of stock and unavailable from AMS or WMO
} 


\section{Weather Reporting: Stations, Data Processing and Transmission}

9 - Weather Reporting

Vol. A Observing Stations: Basic Volume:

Subscription to Supplement Service (Semi-Annual):

Vol. B Data Processing: Basic Volume:

Subscription to Supplement Service (Semi-Annual):

Vol. C Transmissions: Basic Volume:

Subscription to Supplement Service (Bi-Monthly):

Vol. D Information for Shipping: Basic Volume:

Subscription to Supplement Service (Bi-Monthly):

surface mail

134.00

airmail

174.00

78.00

surface mail $\quad 30.00$

airmail $\quad 46.00$

152.00

surface mail $\quad 132.00$

airmail

184.00

183.00

surface mail $\quad 96.00$

airmail

158.00

\section{Operational Manuals}

306 - Manual on Codes

100.00

Vol. I International Meteorological Codes, 1988 Edition

Vol. II Regional Codes and National Coding Practices, 1987 Edition

(w/out cover)

47.00

386 - Manual on the Global Telecommunication System, 1986

$(w /$ cover $)$

60.00

Vol. I Global Aspects

Vol. II Regional Aspects

485 - Manual on the Global Data-Processing System (Vol. I and II one binder)

(w/cover)

161.00

Vol. I Global Aspects, 1977

Vol. II Regional Aspects, 1980

491 - International Operations Handbook for Measurement of Background Atmospheric Pollution, 1978

544 - Manual on the Global Observing System (Vol. I and II one binder), 1981

48.00

35.00

27.00

Guides

8 - Guide to Meteorological Instruments and Observing Practices, 5th Edition, 1983

47.00

100 - Guide to Climatological Practices, 2nd Edition, 1983

39.00

114 - Guide to Qualifications and Training of Meteorological Personnel Employed in the Provision of

13.00 Meteorological Services for International Air Navigation, 1974

134 - Guide to Agricultural Meteorological Practices, 2nd Edition, 1981

29.00

168 - Guide to Hydrological Practices -

Vol. I Data Acquisition and Processing, 1981

Vol. II Analysis, Forecasting and other Applications, 1983

38.00

46.00

27.00

305 - Guide on the Global Data-Processing System, 1982

34.00

471 - Guide to Marine Meteorological Services, 2nd Edition, 1982

488 - Guide on the Global Observing System, 1989

42.00

623 - Guide to the IGOSS Data-Processing and Services System, 1983

7.00

634 - Guidelines for Computerized Data Processing in Operational Hydrology and Land and Water Management,

34.00 1985

636 - Guide on the Automation of Data-Processing Centers, 1985

25.00

702 - WMO guide to Wave Analysis and Forecasting, 1989

47.00

\section{Training Manuals}

240 - Compendium of Training Facilities for Meteorology and Operational Hydrology, 6th Edition, 1982

258 - Guidelines for Education and Training of Personnel in Meteorology and Operational Hydrology, 3rd Edition, 1984

266 - Compendium of Lecture Notes for Training Class IV Meteorological Personnel

Vol. I Earth Science, 1970

Vol. II Meteorology, 2nd Edition, 1984

364 - Compendium of Meteorology for use by Class I and II Meteorological Personnel

Vol. I Part 1 Dynamic Meteorology, 1973*

Part 2 Physical Meteorology, 1973*

Part 3 Synoptic Meteorology, 1978

Vol. II Part 1 Ceneral Hydrology, 1977

Part 2 Aeronautical Meteorology, 1978

Part 3 Marine Meteorology, 1979

Part 4 Tropical Meteorology, 1979

Part 5 Hydrometeorology, 1985

* Currently out of stock and unavailable from AMS or WMO 
Training Manuals (continued)

432 - Proceedings of the WMO/IAMAP Symposium on Education and Training in Meteorology and Meteorological Aspects of Environmental Problems (Caracas, February 1975); 1975

489 - Compendium of Training Facilities in Environmental Problems Related to Meteorology and Operational Hydrology, 1977

493 - Proceedings of the Meeting on Education and Training in Meteorological Aspects of Atmospheric Pollution and Related Environmental Problems, Research Triangle Park, U.S.A., January-February 1977; 1977

593 - Lecture Notes for Training Class IV Agricultural Meteorological Personnel, 1982

622 - Compendium of Lecture Notes on Meteorological Instruments for Training Class III and Class IV Meteorological Personnel, 1986

Vol. I Part 1 Meteorological Instruments

Part 2 Meteorological Instrument Maintenance Workshops, Calibration Laboratories and Routines Vol. II Part 3 Basic Electronics for the Meteorologist

669 - Workbook on Numerical Weather Prediction for the Tropics for the Training of Class I and Class II Meteorological Personnel, 1986

\section{Operational Hydrology Reports}

332 - Manual for Estimation of Probable Maximum Precipitation, O.H.R. 1; 1986

341 - Benefit and Cost Analysis of Hydrological Forecasts. A State-of-the-Art Report, O.H.R. 3; 1973

425 - Hydrological Forecasting Practices, O.H.R. 6; 1975

433 - Hydrological Network Design and Information Transfer. Proceedings of the International Seminar, Newcastle upon Tyne, U.K., August 1974, O.H.R. 8; 1976

461 - Casebook of Examples of Organization and Operation of Hydrological Services, O.H.R. 9; 1977

476 - Hydrological Application of Atmospheric Vapour Flux Analyses, O.H.R. 11; 1977

513 - Applications of Remote Sensing to Hydrology, O.H.R. 12; 1979

519 - Manual on Stream Gauging (2 Vol. set in one binder). O.H.R. 13; 1980

559 - Hydrological Data Transmission, O.H.R. 14; 1981

560 - Selection of Distribution Types for Extremes of Precipitation, O.H.R. 15; 1981

561 - Measurement of River Sediments, O.H.R. 16; 1981

576 - Case Studies of National Hydrological Data Banks (Planning, Development and Organization), O.H.R. 17; 1981

577 - Flash Flood Forecasting, O.H.R. 18; 1981

580 - Concepts and Techniques in Hydrological Network Design, O.H.R. 19; 1982

587 - Long-Range Water-Supply Forecasting, O.H.R. 20; 1982

589 - Methods of Correction for Systematic Error in Point Precipitation Measurement for Operational Use, O.H.R. $21 ; 1982$

635 - Casebook on Operational Assessment of Areal Evaporation, O.H.R. 22; 1985

646 - Intercomparison of Models of Snowmelt Runoff, O.H.R. 23; 1986

650 - Level and Discharge Measurement Under Difficult Conditions, O.H.R. 24; 1986

655 - Tropical Hydrology, O.H.R. 25; 1987

658 - Methods of Measurement and Estimation of Discharges at Hydraulic Structures, O.H.R. 26; 1986

680 - Manual on Water Quality Monitoring, O.H.R. 27, 1988

683 - Hydrological Information Referral Service-INFOHYDRO Manual, O.H.R. 28, 1988

686 - Manual on Operational Methods for Measurements of Sediment Transport, O.H.R. 29; 1989

704 - Hydrological Aspects of Combined Effects on Storm Surges and Heavy Rainfall on River Flow, O.H.R. 30; 1988

705 - Management of Groundwater Observation Programmes, O.H.R. 31

717 - Cost-Benefit Assessment Techniques and User Requirements for Hydrological Data, O.H.R. No. 32*

718 - Statistical Distributions for Flood Frequency Analysis, O.H.R. No. 33*

\section{Special Environment Reports}

372 - A Brief Survey of Meteorology as Related to the Biosphere, S.E.R. 4; 1973

15.00

448 - Weather, Climate and Human Settlements, S.E.R. 7; 1976

15.00

496 - Systems of Evaluating and Predicting the Effects of Weather and Climate on Wildland Fires, S.E.R. 11; 1978

647 - Lectures Presented at the WMO Technical Conference on Observation and Measurements of Atmospheric Contaminants (TECOMAC), S.E.R. 16; 1985

33.00

15.00

26.00

36.00

27.00

13.00

14.00

61.00

8.00

9.00

10.00

15.00

9.00

9.00

9.00

14.00

23.00

51.00

10.00

15.00

10.00

22.00

46.00

15.00

18.00

\section{Technical Notes}

391 - Meteorology and the Colorado Potato Beetle, T.N. 137; 1975

392 - Drought and Agriculture, T.N. 138; 1975

* In preparation 


\section{Technical Notes (continued)}

482 - Forecasting Techniques of Clear Air Turbulence Including that Associated with Mountain Waves, T.N. 155; 1977

487 - Techniques of Frost Prediction and Methods of Frost and Cold Protection, T.N. 157; 1978

40.00

495 - Handbook of Meteorological Forecasting for Soaring Flight, T.N. 158; 1978

497 - Weather and Parasitic Animal Disease, T.N. 159; 1978

23.00

498 - Soya Bean and Weather, T.N. 160; 1978

507 - The Application of Atmospheric Electricity Concepts and Methods to other Parts of Meteorology, T.N. 162; 1978

532 - Meteorological Factors Affecting the Epidemiology of the Cotton Leaf Worm and Pink Bollworm, T.N. 167; 1980

550 - Meteorological and Hydrological Aspects of Sitting and Operation of Nuclear Power Plants, T.N. 170 Vol. I Meteorological Aspects, 1985

Vol. II Hydrological Aspects, 1981

554 - Fog and Reduced Visibility Due to Fog at Aerodromes, T.N. 171; 1985

557 - Meteorological Aspects of the Utilization of Solar Radiation as an Energy Source + Annex: World Maps of Relative Global Radiation, T.N. 172; 1981

575 - Meteorological Aspects of the Utilization of Wind as an Energy Source, T.N. 175; 1981

583 - Tropospheric Chemistry and Air Pollution, T.N. 176; 1982

581 - Review of Atmospheric Diffusion Models for Regulatory Applications, T.N. 177; 1982

591 - Meteorological Aspects of Certain Processes Affecting Soil Degradation - Especially Erosion, T.N. 178; 1983

620 - Weather-Based Mathematical Models for Estimating Development and Ripening of Crops, T.N. 180; 1983

625 - Use of Radar in Meteorology, T.N. 181; 1985

629 - Analysis of Data from International Experiments on Lucerne, T.N. 182; 1985

630 - Severe Convective Weather in Relation to Inflight Phase, T.N. 183; 1985

633 - Land Use and Agro-System Management Under Severe Climatic Conditions, T.N. 184; 1985

641 - Meteorological Observations using NAVAID Methods, T.N. 185; 1985

662 - Land Management in Arid and Semi-Arid Areas, T.N. 186

672 - Applications of Meteorology to Atmospheric Pollution Problems, T.N. 188; 1987

679 - Contribution of Satellite Data and Service to WMO Programs in the Next Ten Years, T.N. 189; 1987

684 - Weather and Climate and Animal Performance, T.N. 190, 1988

685 - Animal Health and Production at Extremes of Weather, T.N. 191; 1988

687 - Agrometeorological Aspects of Operational Crop Protection, T.N. 192; 1988

703 - Agroclimatology of the Sugar Cane Crop, T.N. 193; 1989

36.00

24.00

25.00

13.00

18.00

30.00

$*$
58.00

41.00

17.00

10.00

57.00

16.00

30.00

21.00

25.00

14.00

30.00

12.00

34.00

26.00

29.00

25.00

18.00

\section{World Weather Watch Planning Reports}

553 - Conversion of Grid-Point Data into Meteorological Maps with a Mini-Computer System, W.W.W. 37; 1980 690 - 2nd WMO Long-Term Plan - Part I, 1987

691 - 2nd WMO Long-Term Plan - Part II, Vol. 1, 1987

692 - 2nd WMO Long-Term Plan - Part II, Vol. 2, 1987

693 - 2nd WMO Long-Term Plan - Part II, Vol. 3, 1987

694 - 2nd WMO Long-Term Plan - Part II, Vol. 4, 1987

695 - 2nd WMO Long-Term Plan - Part II, Vol. 5, 1987

696 - 2nd WMO Long-Term Plan - Part II, Vol. 6, 1987

\section{World Weather Watch Status Reports}

674 - World Weather Watch 13th Status Report on Implementation, 1987

714 - World Weather Watch - 14th Status Report on Implementation, 1989

\section{General Reference Publications}

2 - Meteorological Services of the World, 1985

47 - International List of Selected, Supplementary and Auxiliary Ships, 1985

64.00

174 - Catalogue of Meteorological Data for Research

Part I Published Synoptic and Climatological Data, 1965

Part II Meteorological Stations with Observational Series Extending Over 80 Years or More, 1970

55.00

Part III Meteorological Data Recorded on Media Usable by Automatic Data-Processing Machines, 1972

Part IV Sources of Additional Data Needed for Research on Climatic Change, 1979

38.00

25.00

57.00

20.00

259 - WMO Sea-Ice Nomenclature 1970 (Vol I and III one binder)

34.00

Vol. I Terminology and Codes

Vol. II Illustrated Glossary (out of print)

Vol. III International System of Sea Ice Symbols

634 - Guidelines for Comprehensive Data-Processing in Operational Hydrology and Land Water Management, 1985

665 - Guidance Material on the Calculation of Climatic Parameters Used for Building Purposes 


\section{Publications of General Interest}

385 - International Glossary of Hydrology, 1974

411 - Information on Meteorological and Other Environmental Satellites, 1989

50.00

420 - Proceedings of a WMO Technical Conference on Automated Meteorological Systems (TECAMS), Washington, D.C., February $1975 ; 1975$

463 - Weather and Water, 1977

477 - Solar Energy, Proceedings of the WMO/UNESCO Symposium, Geneva, August-September 1976; 1977

523 - The Atmosphere Boundary Layer, 1979

537 - Proceedings of the World Climate Conference - A Conference of Experts on Climate and Mankind, Geneva, February 1979; 1979

542 - Climatic Changes and Their Effects on the Biosphere, 1980

543 - Man and Climatic Variability, 1980

574 - Sea-Ice Information Services in the World, 1981

585 - Satellites in Meteorology, Oceanography and Hydrology, 1982

596 - Proceedings of the Technical Conference on Climate - Africa (Arusha, 25-30 January 1982); 1982

608 - Twentieth Anniversary of the World Weather Watch - Opportunities and Outlook for Improved World Weather Watch, 1983

613 - Monsoons, 1986

624 - Meteorology Aids Food Production, 1985

630 - Severe Convective Weather in Relation to the In-Flight Phase

632 - Proceedings of the Climate Conference for Latin America and the Carribean 1983, 1984

652 - Proceedings of the Technical Conference on Urban Climatology and Its Applications With Special Regard to Tropical Areas (Mexico D.F., 26-30 November 1984); 1986

653 - Climate Variations, Drought and Desertification, 1985

661 - Report of the International Conference on the Assessment of the Role of Carbon Dioxide and of Other Greenhouse Gases in Climate Variations and Associated Impacts, 1986

667 - Meteorology - A Model of International Cooperation, 1986

683 - Weather and Climate and Animal Performance, 1987

688 - Meteorology and the Media, 1987

700 - Dispersion Processes in Large Scale Weather Prediction-6th IMO Lecture, 1989

706 - Meteorology in the Service of Aviation by J. Kastelein

708 - The Bulletin Interviews

709 - World Weather Watch 40th Anniversary Brochure, 1989

710 - The Changing Atmosphere-Proceedings of the Toronto Conference, 1989

712 - Mesoscale Forecasting and Its Applications: Lectures Presented at the 40th Session of EC, 1989

716 - Papers Submitted to the Fifth Scientific Conference on Weather Modification and Applied Physics, Volumes I and II

721 - A Historical Review of WMO*

722 - National Disaster Preparedness: How Meteorologist and Hydrological Services Can Help*

\section{Commission, Congress, Executive, and Annual Reports}

508 - Resolutions of Congress and Executive Committee, 1985

590 - Commission for Instruments and Methods of Observation - Abridged Final Report of the 8th Session (1981) (CIMO), 1982

598 - Commission for Atmospheric Sciences - Abridged Final Report of the 8th Session (CAS), 1982

602 - Commission for Aeronautical Meteorology - Abridged Final Report of the 7th Session (CAM), 1982

603 - Long-Range Transport of Sulphur in the Atmosphere and Acid Rain - Lectures Presented at the 33rd Session of the WMO Executive Committee, 1983

606 - Annual Report of the World Meteorological Organization, 1982-83; 1983

614 - Scientific Lectures Presented at the 9th World Meteorological Congress, Geneva 1983; 1985

615 - Ninth World Meteorological Congress - Abridged Report with Resolutions, 1983

619 - WMO Executive Council 35th Session - Abridged Final Report with Resolutions, 1983

640 - Commission for Marine Meteorology - Abridged Final Report of the 9th Session (CMM), 1985

644 - Annual Report of the World Meteorological Organization (1984); 1985

645 - Ninth World Meteorological Congress - Proceedings, 1985

648 - WMO Executive Committee 36th Session - Abridged Final Report with Resolutions, 1984

649 - Scientific Lectures Presented at the 36th Session of the WMO Executive Committee, 1984

651 - Commission for Instrument and Methods of Observation - Abridged Final Report of the 9th Session (CIMO) (1982) 1986

654 - Commission for Basic Systems Abridged Final 1985 Session (CBS), 1986

45.00

24.00

29.00

29.00

12.00

31.00

14.00

39.00

29.00

29.00

32.00

35.00

31.00

12.00

30.00

656 - Annual Report of the World Meteorological Organization (1985); 1986

36.00

660 - Commission for Climatology and Application of Meteorology 9th Session, 1986

\footnotetext{
* In preparation
} 


\section{Commission, Congress, Executive and Annual Reports (continued)}

663 - Satellite Observations in Environment Assessments (38th Executive Council), 1986

668 - WMO Executive Council 38th Session Abridged Final Report, 1986

671 - Commission for Atmospheric Sciences Abridged Final 9th Session (CAS), 1986

26.00

673 - Commission for Aeronautical Meteorology Abridged Final 8th Session (CAEM), 1987

675 - Water - Lectures Presented at the 38th Session of WMO Executive, 1987

676 - Annual Report of the World Meteorological Organization, (1986); 1987

677 - Commission for Agricultural Meteorology Abridged Final 9th Session (CACM), (1986); 1987

681 - 10th World Meteorological Congress Abridged Report with Resolutions, 1988

682 - WMO Executive Council 39th Session Abridged Final Report, (1987); 1988

689 - Annual Report of the World Meteorological Organization, (1987); 1988

713 - Annual Report of the World Meteorological Organization (1988), 1989

715 - Commission for Hydrology Abridged Final Report of the Eighth Session (CHY), 1989

720 - Commission for Climatology: Abridged Final Report of the Tenth Session (1989)*

723 - Forty-First Session of the Executive Council (1989): Abridged Report with Resolutions*

\section{Reports of Sessions of Regional Associations}

524 - Regional Association IV (North and Central America) - Hurricane Operational Plan, 1989

594 - Regional Association III (South America) - Abridged Final Report of the 8th Session, 1982

642 - Regional Association II (Asia) - Abridged Final Report of the 8th Session (1982); 1983

28.00

664 - Regional Association V (South-West-Pacific) Abridged Final Report, (1986); 1987

28.00

666 - Regional Association III (South America) - Abridged Final Report of the 9th Session, (1986); 1987

25.00

670 - Regional Association IV (Europe) 9th Session Abridged with Resolutions, (1986); 1987

34.00

678 - Regional Association I (Africa) 9th Session Final Report Council, (1987); 1988

711 - Regional Association II (Asia) 9th Session Abridged Final Report, 1989

33.00

719 - Regional Association IV: Abridged Final Report of the Tenth Session*

\section{GARP Special Reports}

Report of the Seminar on Progress in Diagnostic Studies of the Global Atmospheric Circulation as a Result of the

Global Weather Experiment (August 1984), No. 42; 1985

Report of the Seminar on Progress in Numerical Modelling and the Understanding of Predictability as a Result of the

Global Weather Experiment (October 1984), No. 43; 1985

Report of the Seminar on Progress in Tropical Meteorology as a Result of the Global Weather Experiment (October 1984), No. 44; 1985

WMO Cloud Sheet, 1986.

The dimensions of the new edition of the WMO Cloud Sheet are $39 \times 83 \mathrm{~cm}$. This popular sheet is printed on glossy paper and can be mounted on a hard backing. There are 38 color photographs from the International Cloud Atlas. These were selected to assist not only the marine observer, but also as a general reference for all professional or amateur meteorological observers.

\section{QUANTITY}

$$
\begin{gathered}
1-10 \\
11-30 \\
31-50 \\
51-100 \\
101-500 \\
501-1000 \\
1000+
\end{gathered}
$$

PRICE PER CLOUD SHEET

(Prices do not include Shipping and Handling)
$\$ 5.00$
$\$ 4.00$
$\$ 3.00$
$\$ 2.75$
$\$ 2.50$
$\$ 2.25$
$\$ 2.00$

Shipping and Handling Charges: 1-10 \$4.00/sheet; $11-100 \$ 8.00 / 10$ sheet; $100+$ Contact AMS for shipping and handling costs for orders over 100 sheets.

\footnotetext{
* In preparation
} 


\section{AMERICAN METEOROLOGICAL SOCIETY \\ Presents A Special Program on HURRICANE HUGO}

February 7, 1990

\section{0th AMS Annual Meeting \\ Disneyland Hotel}

Call for Presentations

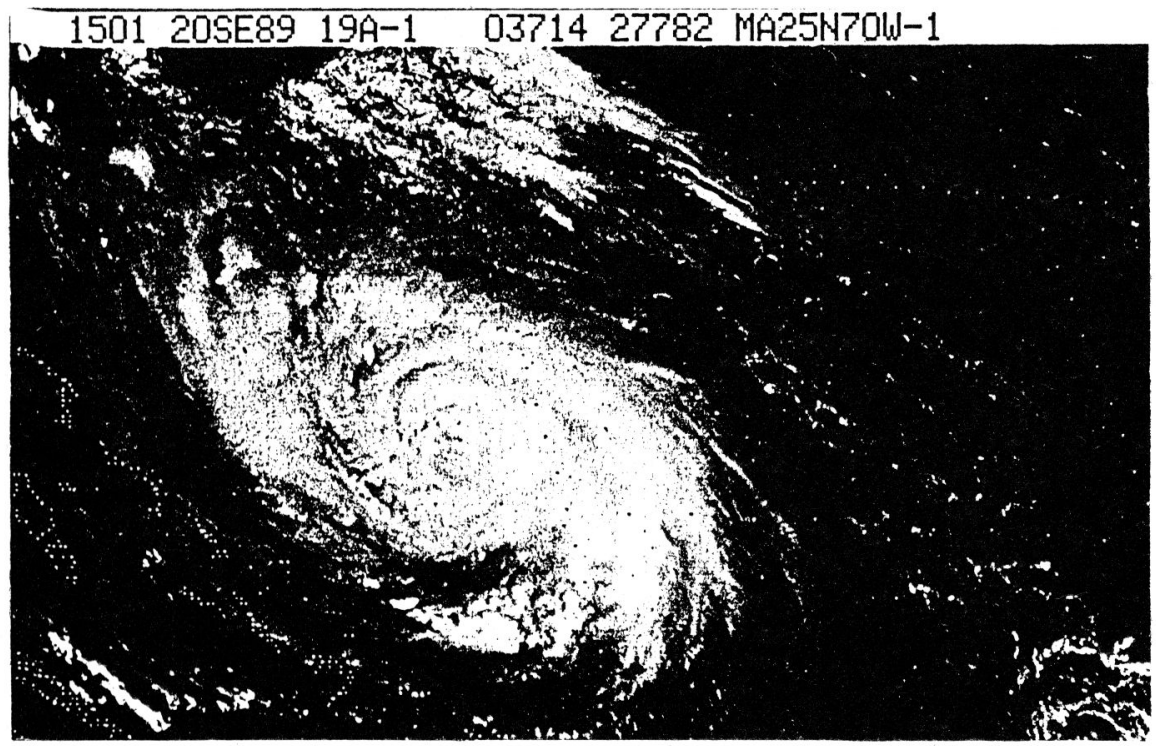

On September 13, 1989 Hurricane Hugo reached hurricane strength. On the 15th Hugo's winds reached $150 \mathrm{mph}$. It made landfall on the island of Guadal upe on the 16th of September. Between the 16th and 21st of September, Hugo left a path of destruction in its wake. Damages are estimated to exceed $\$ 5$ billion for the U.S. and the Caribbean islands. Forty-seven people died and thousands were left homeless.

**Satellite photograph courtesy of WRC-TV

Due to the significance of Hurricane HUGO, AMS has scheduled a special program at the 70th AMS Annual Meeting. This program will be held on Wednesday, February 7, 1990, from 1:00 pm to 5:00 pm. Two sessions are planned.

This program will be chaired by Dr. Robert Sheets, Director of the National Hurricane Center (NHC) and Dr. Stanley Rosenthal of the Hurricane Research Division (HRD). Dr. Sheets will provide overview of the storm. A broad overview of the storm and important aspects of the storm will be presented. Video, computer presentations and poster formats will be used for a majority of the presentations. The AMS Board on Broadcast Meteorology has prepared a video tape highlight of Hugo. This tape includes input from several TV stations located in path of the storm. The organizations and program committee includes:

\section{National Hurricane Center (NHC), Robert Sheets, Director}

Hurricane Research Division (HRD), Stanley Rosenthal, Director

AMS Board on Broadcast Meteorology, Allan Eustis, Chairman

AMS Committee on Satellite Meteorology and Oceanography, Philip Durkee, Chairman

AMS Committee on Tropical Meteorology and Tropical Cyclones, Stephen Lord, Chairman

$\square$ AMS Committee on Radar Meteorology, Frank Marks, Chairman

AMS Committee on Weather Analysis and Forecasting, Laurence Lee, Chairman

Although the deadline for submission of abstracts has passed, if you would like to present any important aspect of Hugo, please send your abstract to: 